\title{
Opinions of clients of cosmetology salons regarding the impact of wearing protective masks on the condition of the skin
}

\section{Opinie klientów gabinetów kosmetologicznych dotyczace uplywu noszenia maseczek ochronnych na kondycję skóry}

\begin{abstract}
Acne vulgaris is a common condition that affects both men and women of all age groups. As a result of the outbreak of the COVID-19 pandemic and the introduction of restrictions, mainly the obligation to cover the nose and mouth with protective masks, a large percentage of the population is now struggling with acne.

The aim of the research was to determine the opinion on the impact of wearing protective masks on the deterioration of the skin condition and the awareness of the respondents about the treatments and preparations used in acne therapy. The article also attempted to explain the causes of acne lesions.
\end{abstract}

Keywords: Acne vulgaris, mascne, microbiome, skin, protective masks

\section{STRESZCZENIE}

Trądzik pospolity jest popularną chorobą, która dotyka zarówno kobiet, jak i mężczyzn w różnym przedziale wiekowym. W wyniku wybuchu pandemii COVID-19, której następstwem było nałożenie obostrzeń, głównie obowiązku zasłaniania nosa i ust maseczkami ochronnymi, zaobserwowano nasilenie problemu trądziku wśród znacznej części społeczeństwa.

Celem badań było poznanie opinii na temat wpływu noszenia maseczek ochronnych na pogorszenie kondycji skóry oraz świadomość badanych na temat zabiegów i preparatów wykorzystywanych w terapii. W artykule podjęta została również próba wyjaśnienia przyczyn powstawania zmian trądzikowych.

Słowa kluczowe: trądzik pospolity, maskne, mikrobiom, skóra, maseczki ochronne

\section{INTRODUCTION}

The first cases of the COVID-19 disease caused by the SARSCoV-2 coronavirus date back to November 17, 2019. The outbreak of the pandemic, announced in spring 2020, had a negative impact on the condition of the skin of many peo- ple. As a result of the restrictions wearing protective masks covering the nose and mouth became obligatory. Many people, including those who had no problems with the skin before, noticed the appearance of acne lesions, excessive irritation and redness of the skin. 


\section{ACNE VULGARIS}

Acne vulgaris is a chronic, inflammatory disease of the sebaceous hair unit caused by increased sebum secretion. Excessive production is triggered by androgens, a change in keratinization and colonization of hair follicles by Cutibacterium acnes (C. acnes) in the area of the face, neck, back and chest [1]. The changes become apparent when the keratinocytes covering the hair follicles begin to shed, forming a microcomedon. During the maturation period, the production of sebum increases, which creates an environment conducive to the colonization of $C$. acnes. During the process of bacterial multiplication, chemotactic and inflammatory mediators are produced, driving inflammatory processes [2]. The symptoms of acne vulgaris include primary lesions like micro-blackheads, which are lesions detected only under a microscope, transforming into a macroscopically visible blackhead. We can distinguish two types of blackheads: open (the top of the hair follicle is filled with oxidized keratin, which gives it a black color and is visible) and closed (the top of the hair follicle is not visible). Within the lesions, depending on the variety, the following inflammatory lesions are distinguished: pustules, tumors, papules, cysts with fistulas and scars. Another characteristic feature is seborrhea, which is defined as excessive secretion of sebum by the sebaceous glands that reach the skin surface [3].

\section{THE SKIN MICROBIOM}

The human organism is a habitat of microorganisms, which makes it a set of ecosystems with microorganisms of separate species. The skin is the largest and most external organ of the human body, the primary function of which is to connect the body with the external environment and protect it against the negative influence of environmental factors. Individual areas of the skin differ in the thickness of the epidermis, humidity and temperature on the surface, and the location of appendages. These features have a significant impact on the quantitative and species composition of the microflora. Most of the microorganisms found on the skin are not harmful, but coexist with the skin cells. Human skin is inhabited by bacteria, viruses, fungi and mites. The group of bacteria found on the skin consists of over 1000 species, but is mainly inhabited by four types: Actinobacteria, Bacteroidetes, Firmicutes and Proteobacteria [4]. Human skin is also inhabited by pathogenic bacteria, including golden staphylococcus (S. ureus), aerobic coryneform bacteria (Corynebacterium spp.), group A streptococci (S. pyogenes) and gram-negative bacilli ( $P$. aeruginosa). These microorganisms create undesirable flora that can lead to skin infections. Due to the presence of its own microflora, the multiplication of these bacteria is difficult and the infection can occur only when the physicochemical conditions are disturbed, the skin is broken, in the case of treatment with antibiotics or in the presence of foreign bodies (such as artificial valves, catheters) [5]. The predominant species of fungi that inhabit the skin are Malassezia fungi, accounting for $1-22 \%$ of the microbiome. Under appropriate conditions, they can contribute to the appearance of dermatological diseases and systemic infections in case of a significant decrease in immunity. The most common diseases caused by fungi are tinea versicolor and folliculitis, but they also affect the course of atopic dermatitis and seborrheic dermatitis. The microbiome, apart from bacteria and fungi, includes Demodex, which are parasitic arachnids belonging to the mite order, inhabiting the sebaceous glands and hair follicles [4].

Both genetic and external factors, such as $\mathrm{pH}$ and temperature, affect the skin microbe. The disturbance of the normal microbiome associated with wearing masks contributes to the development of many dermatological diseases, for instance acne, eczema and peroral dermatitis. An important factor influencing the composition of the microbiome is water, which determines the increase in the number of microorganisms, therefore, in areas with high humidity, numerous commensal microflora is observed. Microflora dispersion leads to the division of pathogenic and virulent strains of $C$. acnes, and also activates the innate immunity causing skin inflammation [6].

\section{THE DEVELOPMENT OF ACNE}

Scientific reports suggest that acne is considerably caused by genetic factors. A positive family history of acne is associated with its earlier manifestation, resistance to treatment and more severe course. Cytogenetic studies indicate the genetic basis of the disease [3, 7].

Excessive sebum production refers to most patients and is one of the key factors in the acne development process. Androgens act on the growth of sebaceous glands, keratinization of the sebaceous ducts and increase sebum secretion. Their main source is the adrenal glands, testicles and ovaries. Dihydrotestosterone (DHT) and testosterone have the greatest influence on the metabolism of the sebaceous glands. An important role in the pathogenesis of acne is played by $5 \alpha$-reductase, which is an enzyme that determines the conversion of testosterone into DHT [8]. The androgen-receptor configuration can express genes that are responsible for the proliferation of sebaceous cells, lipogenesis and growth of the sebaceous gland [9].

Disturbance in the process of keratinization of the ducts leading out of the sebaceous glands results in excessive keratinization and adhesion of exfoliated scales in the area of the sebaceous gland funnel. Additionally, a reduction of the sebaceous canal allows the free excretion of sebum to the skin surface, which leads to the formation of micro-blackheads, often transforming into open and closed comedones [10]. Micro-blackheads are formed under the influence of 
many factors, including excessive androgen secretion, linoleic acid deficiency or excess free fatty acids [11]. The factor that determines the transformation of microcomedals into comedones is follicular keratinization, caused by irritation of the hair follicle walls by bacteria and sebaceous material, which may lead to overproduction and accumulation of corneocytes [12].

The state of chronic mental stress may lead to an increase in the secretion of adrenal androgens, stimulates the increased activity and growth of the sebaceous gland, and the production of cytokines [13].

The course of the disease can also be influenced by the season and climate. In case of people with excessive sweating, acne lesions appear in the area characterized by a large number of sebaceous glands, in the so-called $\mathrm{T}$ zone - forehead, nose and chin area, interscapular area and cleavage, especially when the humid and hot climate. Notably, in places particularly exposed to ultraviolet UV radiation, follicular lumps appear [3].

While struggling with acne changes, many people make skin care mistakes that aggravate the problem. It is crucial to avoid excessive mechanical damage to the skin without sufficient hygiene, self-removal of lesions, use of comedogenic cosmetics (including foundations, powders, containing paraffins, parabens, silicones and esters, leading to the formation of blackheads and acne lesions) and too frequent washing with ordinary soap. It may seem that excessive drying of the skin with substances such as ethyl alcohol or stronger detergents such as SLS (Sodium Lauryl Sulfate) or SLeS (Sodium Laureth Sulfate) have a positive effect of removing excess sebum, but they result in the violation of the epidermal barrier, drying out and increasing the ability to irritate the skin and exacerbating the course of acne [14].

\section{MASCNE}

Coronaviruses belong to the group of viruses that cause serious respiratory diseases. In 2019, a new coronavirus (SARS-CoV-2) appeared in China, which initially caused an epidemic, and then a pandemic that spread across the globe. Due to the ease of infection with the new virus strain, the obligation to wear protective masks was introduced. A first it only concerned the health service, but over time it became a general requirement for the entire population. Chafes and injuries to the bridge of the nose, cheeks and forehead have been reported in health care workers due to the pressure exerted by the masks [15]. As a result of the obligation to wear protective masks, an increase in the disease and intensification of acne symptoms caused by wearing protective masks was noticed. This phenomenon has been named "mascne". The use of masks may also contribute to the formation of mechanical acne (acne mechanica), which is a type of acne vulgaris and is caused by rubbing and, as a result, blocking the sebaceous glands.
Wearing a mask also exacerbates acne due to sweating and increased humidity, which leads to swelling of the epidermal keratinocytes. Changes in the surface composition of sebum and skin hydration may disturb the epidermal barrier, leading to changes in the skin microflora [16]. Wearing masks increases the temperature of the skin, resulting in extending sweat retention in healthy people and worsening of symptoms in people suffering from hyperhidrosis. A warm and humid microenvironment created by wearing masks increases the skin's susceptibility to fungal infections, for instance candidiasis and malassezia, which are common commensals of healthy skin. Wearing masks affects the infection of the skin with microorganisms that colonize wet areas, such as Staphylococcus and Corynebacteria [6].

\section{ACNE THERAPY}

Popular chemical substances that are used in the treatment of acne are organic acids, and the treatment based on the action of these substances is called a chemical peeling. It involves the controlled application of particular organic acids to the skin surface. The depth of exfoliation depends on the type of substance, concentration and duration of contact time with the skin [17]. Preparations of concentration up to $4 \%$ weaken the adhesion of corneocytes, which results in the removal of keratinized epidermis. Higher concentrations of acids and, at the same time, low $\mathrm{pH}$ affect epidermolysis as a result of the breakage of desmosomal connections of the basal layer of the epidermis. As a result of exfoliation of the appropriate layers of the epidermis, the proliferation of keratinocytes in the basal layer of the epidermis is stimulated. At the same time, increased processes of collagen and extracellular matrix production occurring in the dermis are observed [18]. In addition, these substances are often used in various cosmetic preparations due to the properties of lowering the $\mathrm{pH}$ of the skin and the preparation, which protects against the multiplication of microorganisms.

- The IPL (Intense Pulse Light) device emits polychromatic light, which, in addition to inhibiting the growth of bacteria and photoactivation of porphyrins, leads to photothermolysis by activating endogenous porphyrins in the skin, producing enough energy and heat to hit the blood vessels in the sebaceous glands, cause a reduction in sebum production [19].

In acne therapy, lasers are aimed mainly at accelerating wound healing and reducing seborrhea. The effect of high-energy lasers, which are mostly intended at the treatment of acne lesions, is the flattening of scars and other deformations and the smoothing of the skin [20].

- Retinoids are derived from vitamin A and are administered topically or orally. The treatment of light forms of acne, taking the form of small pimples and papules, 
blackheads and excessive seborrhea is mainly based on the use of external preparations with the addition of this substance. The essence of the action of retinoids is to reduce the adhesion of corneocytes, regulate keratinization and support the natural exfoliation process of the stratum corneum. As a result, they inhibit the formation of micro-blackheads, which form blackheads, pimples and papules, and also soothe existing inflammations. However, they do not have sebostatic effect, so constant seborrhea may delay the success of the treatment. The beginning of the treatment can be challenging for patients due to irritation, redness, dryness and exfoliation of the epidermis, therefore it is recommended to use the preparations every two days and, obligatorily, to moisturize the treated area [21-23].

- Treatment of more severe forms of acne consists of oral administration of isotretinoin, the only drug that acts on the processes of acne formation. In contrary to topical retinoids, isotretinoin reduces and effectively inhibits the work of sebaceous glands, also prevents comedogenesis by regulating the keratinization process and reduces inflammation. This substance also exhibits an antibacterial effect, thanks to which reduces the colonization of $\mathrm{C}$. acnes in the sebaceous glands and hair follicles. Isotretinoin therapy has many side effects, such as: hair loss, excessive drying of the mucosa and skin, pain in muscles and joints, disturbances in the functioning of the liver, and rarely mental disorders [21, 22, 24, 25].

\section{AIM OF THE STUDY}

The aim of the research was to find out the opinion on the impact of wearing protective masks on the deterioration of the skin condition of the respondents and their awareness of cosmetology products and treatments used, among others in acne therapy.

\section{MATERIAL AND METHODS}

An anonymous questionnaire prepared by the authors using a Google Form was published on the Internet. The survey consisted of 20 questions, including 18 closed and 2 open. The first 4 questions contained information on gender, age, place of residence and education. Questions from 5 to 20 concerned the studied problem. The study involved 570 people, including 551 women, which accounted for almost $97 \%$ of all respondents, and 19 men (only $3 \%$ of the respondents). Analysis of performed tests and charts were developed in MS Excel.

\section{RESULTS}

Before the obligation to wear protective masks, $48 \%$ of respondents faced the problem of acne (Fig. 1), while as a result of imposed restrictions, the appearance of skin lesions was declared by as many as $84 \%$ of respondents (Fig. 2).

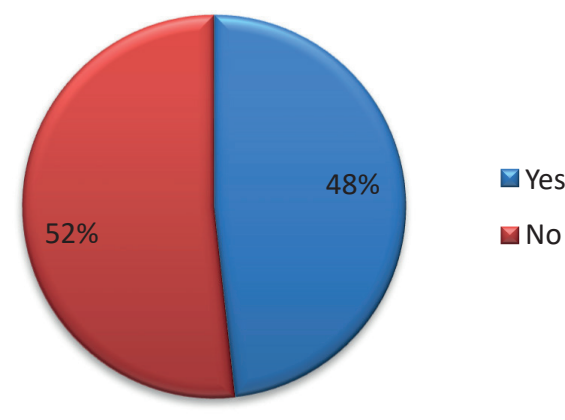

Fig. 1 The presence of acne before wearing face masks Source: Own study.

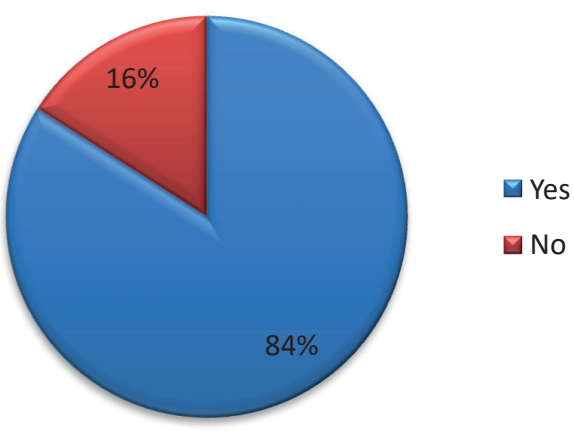

Fig. 2 The appearance of skin lesions as a result of wearing masks Source: Own study.

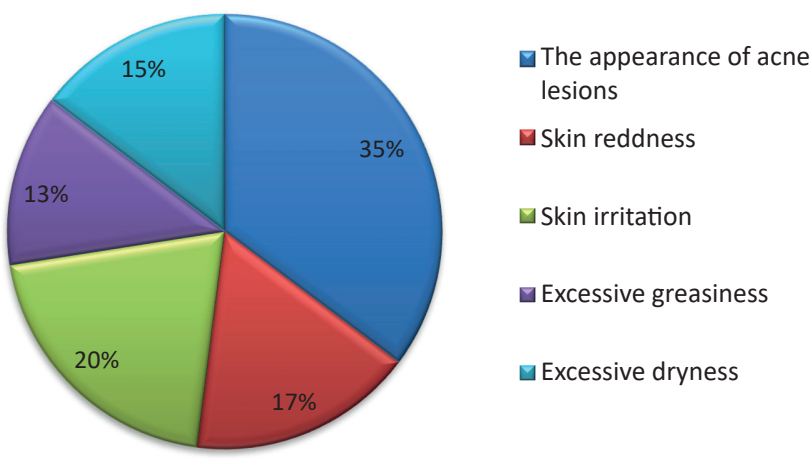

Fig. 3 Types of skin lesions that appeared as a result of wearing masks Source: Own study.

Most respondents (35\%) declared the appearance of acne lesions as a result of wearing masks, $20 \%$ noticed skin irritation, $17 \%$ of respondents indicated the appearance of reddening of the skin, 15\% indicated excessive skin dryness, while excessive oily skin was chosen by $13 \%$ of respondents.

When going to public places (shops, pharmacies), a mask was worn by $43 \%$ of respondents, $30 \%$ spent $2-4$ hours in them, $17 \%$ of respondents walked in them for 8 hours at work, and $10 \%$ wore them for more than 8 hours.

Only $12 \%$ of respondents used anti-acne treatments offered by beauty salons.

As many as $92 \%$ of the respondents did not use the professional skin moisturizing treatments offered by beauty salons. 


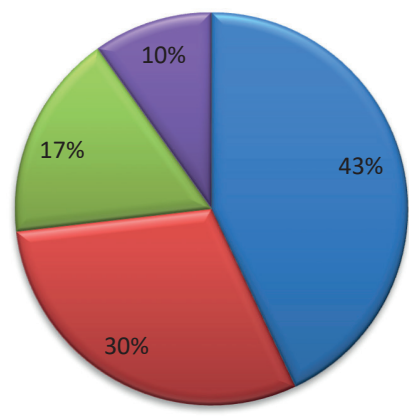

Fig. 4. Time of wearing protective masks Source: Own study.

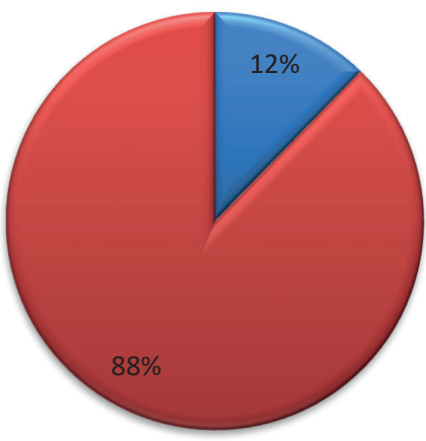

$\square$ Yes

$\square$ No

Fig. 5. Using anti-acne treatments in a cosmetology office Source: Own study.

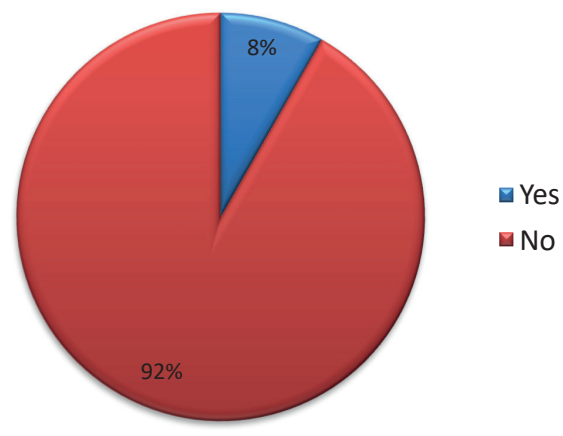

Fig. 6 Using moisturizing treatments in a cosmetology office Source: Own study.

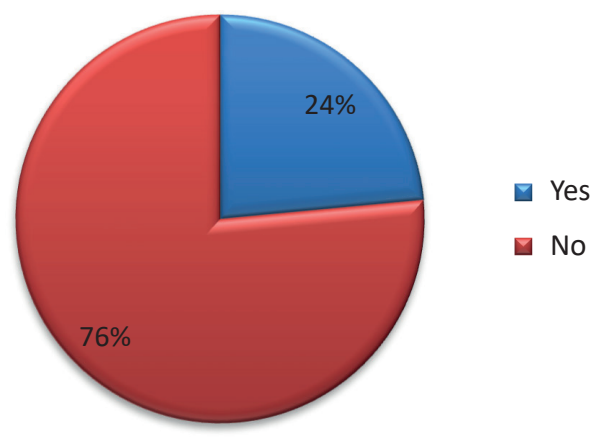

Fig. 7 Using cosmetology procedures before wearing masks Source: Own study.

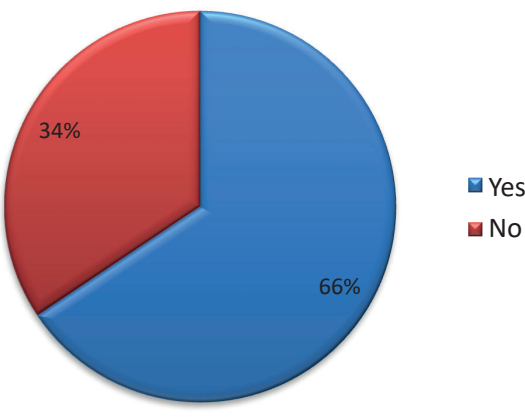

Fig. 8. The use of substances to fight a given problem Source: own study

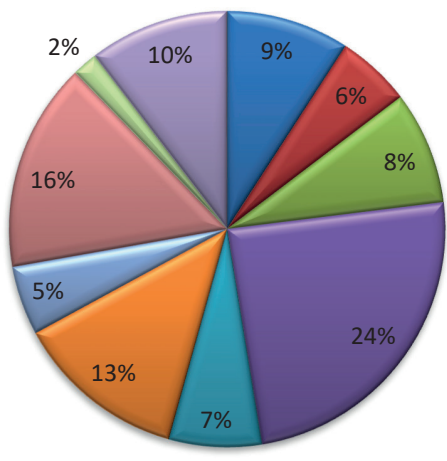

- Salicylic acid

- Mandelic acid

$\square$ Glycolic acid

$\square$ Vitamine C

$\square$ Retinol

$\square$ Hyaluronic acid

$\square$ Azelaic acid

$\square$ Zinc

$\checkmark$ Lactobionic acid

$\square$ Emollients

Fig. 9 Active substances used in relation to emerging skin problems Source: Own study.

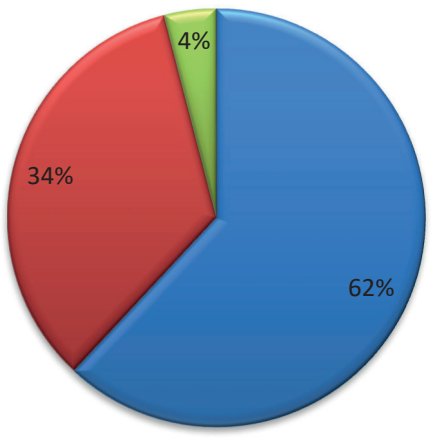

$\square$ Yes

No

$\square$ Not concerned

Fig. 10 Wearing makeup under a mask Source: Own study.

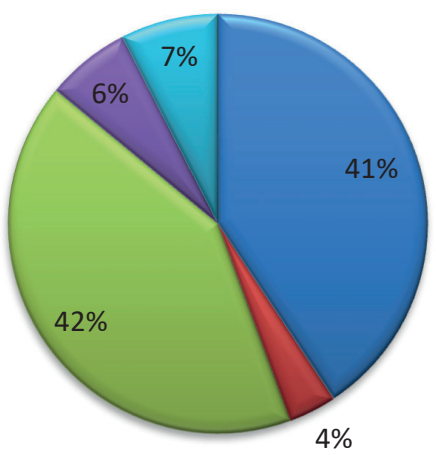

Discard after each use

$\square$ Spray with disinfectant

$\square$ Wash at 60 celsius degrees

Dip in boiling water

$\square$ Iron

Fig. $11 \mathrm{~A}$ way of maintaining a reusable mask Source: Own study. 
Before the obligation to wear protective masks, only $24 \%$ of respondents used cosmetological procedures.

In order to overcome the problem, active substances were used by $66 \%$ of the respondents, while $34 \%$ of the respondents did not use such products.

The vast majority of people (24\%) used products with vitamin $\mathrm{C}$ in their care, $16 \%$ of the respondents used cosmetics containing zinc, slightly less, $13 \%$ declared that they used hyaluronic acid in their care, while only $2 \%$ chose preparations with lactobionic acid.

Applying makeup under the mask was indicated by $62 \%$ of respondents, $34 \%$ of people did not use any makeup before putting on the mask, while $4 \%$ of respondents were not concerned with this question.

In the case of maintaining the protective mask, most respondents (42\%) chose the option of washing at a temperature of at least 60 degrees, slightly less, because $41 \%$ of respondents declared to throw away the mask after each use, while the least, because only $4 \%$ of respondents declared that they spray the mask with a liquid detergent.

\section{DISCUSSION}

The problem of acne or excessive skin irritation is still popular in the society. But as a result of restrictions introduced by the government in the spring of 2020, which required covering the nose and mouth with a protective mask, there was an increase in number of people seeking help from dermatologists or cosmetologists due to the deterioration of their skin condition and the appearance of various skin lesions.

The main aim of the study was to demonstrate the appearance of skin problems as a result of an obligation to wear masks. When asked about the problem of acne before the obligation to cover the nose and mouth, more than a half of the respondents (52\%) answered negative, and to the questions about skin irritation and redness, the vast majority also declared that they had no such problems. The respondents were also asked about the appearance of skin changes as a result of wearing masks, and here as many as $84 \%$ declared that such problems appeared. In the case of determining the most common changes occurring as a consequence of covering the nose and mouth, by far the largest percentage (over $80 \%$ of respondents) declared the appearance of acne lesions, $48 \%$ of respondents indicated the skin irritation, redness and dry skin were also a frequent problem. Previously, Jongwook Kim et al. demonstrated that the use of protective masks increased the redness and the temperature of the skin, moreover, the volume of pores and the number of acne lesions also augmented, which shows that the use of masks has a negative effect on the skin. The changes appeared due to sweating and increased humidity, which leads to swelling of epidermal keratinocytes. More- over, changes in the superficial composition of sebum and skin hydration disrupted the epidermal barrier, leading to alterations in the skin microflora. A warm and humid microenvironment created by wearing masks increases the skin's susceptibility to bacterial and fungal infections [16].

The research indicated that before the obligation to cover the nose and mouth, almost $24 \%$ of the respondents used cosmetological procedures, which is not a satisfactory result. In the case of emerging acne problems, only $12 \%$ of respondents used treatments supporting the reduction of lesions, while only $8 \%$ of respondents used treatments supporting hydration. In similar studies conducted by Ms Paulina Spaleniak and Małgorzata Chmielowska, 36\% of respondents declared that helplessness in coping with the problem. Such results might be caused by insufficient knowledge of the respondents about the operation and the course of individual treatments, performed in both cosmetology and dermatology clinics [26].

An important aspect was also applying makeup under the mask. Among the respondents, 353 people declared that they applied make-up before putting on the mask. This could partially contribute to the formation of acne lesions, due to the comedogenic properties of some makeup cosmetics, leading to inflammation. Due to protective masks, convenient conditions (increase in temperature and humidity) for the disturbance of the microbiome and the multiplication of bacteria are created. It indirectly contributes to the appearance of inflammation and the development of acne.

\section{CONCLUSIONS}

The conducted research confirmed that the introduced restrictions in the for of the obligation to wear masks had a significant impact on the deterioration of the skin condition in the society, and the most common problems ware acne lesions, redness, irritation and excessive drying in the area exposed to direct contact with a protective mask. To the causes of the lesions belonged temperature and humidity, which disturbed microbiome homeostasis. Moreover, low public awareness of the available treatments and preparations for specific problems was demonstrated, which may be caused by insufficient knowledge of these issues. Applying makeup under the mask could have an impact on the formation of acne lesions by using comedogenic substances in cosmetics that provoke the formation of blackheads and acne lesions.

\section{REFERENCES / LITERATURA}

1. Williams HC, Dellavalle RP, Garner S. Acnevulgaris. The Lancet. 2012;379(9813):361-372.

2. Webster GF. Patofizjologia trądziku. Cutis. 2005;76(Supl. 2):4-7

3. Kołodziejczak A. Kosmetologia Tom I. Warszawa: Wyd. PZWL; 2019.

4. Adamczyk K, Garncarczyk A, Antończak P. Mikrobiom skóry. Przegląd Dermatologiczny. 2018;105:285-297. 
5. Reid G, Younes JA, Van der Mei HC, et al. Microbiota restoration: natural and supplemented recovery of human microbial communities. Nat Rev Microbiol. 2011;9:27-38.

6. Wan-Lin T. The "Maskne" microbiome - pathophysiology and therapeutics. International Journal of Dermatology. 2021;60(7):799-809. https://doi.org/10.1111/ijd.15425

7. Sobjanek M, Zabłotna M, Sokołowska-Wojdyło M, et al. Czynniki genetyczne w etiopatogenezie trądziku pospolitego. Post Dermatol Alergol. 2007; 24(4):183-187.

8. Sobjanek M, Sokołowska-Wojdyło M, Barańska-Rybak W, et al. Rola czynników hormonalnych w etiopatogenezie i terapii trądziku pospolitego. Post Dermatol Alergol. 2006;23(6):266-272.

9. Deplewski D, Rosenfield RL. Role of hormones in pilosebaceous unit development. Endocr Rev. 2000;21:363-392.

10.Biegaj M. Trądzik pospolity i jego leczenie. Kosmetologia Estetyczna. 2017;6(2):155-158.

11. Thiboutot D. Pathogenesis and treatment of acne. J Eur Acad Dermatol Venereol. 2001;15:91.

12. Wolska H. Rola terapii kojarzonej w trądziku. Derm Klin i Zabieg. 2001;3:129.

13. Sobjanek M, Sokołowska-Wojdyło M, Binkowska-Michalik K, et al. Trądzik wieku dorosłego - interdyscyplinarny problem kliniczny. Przegl Dermatol. 2006;4(93):475-481.

14.Szmaj-Kupny E, Kuś M. Trądzik pospolity w ujęciu holistycznym. Aesth Cosmetol Med. 2020;9(4):389-393.
15. Hayat W, Mahmood Malik L, Mukhtar R, et al. “Maskne” (Mask Induced Acne) in health care professionals of tertiary care hospitals of lahore during COVID-19 pandemic. Pak Postgrad Med J. 2020;31(2):61-65.

16. Gomolin TA, Cline A, Russo M. Maskne: Exacerbation or Eruption of Acne During the COVID-19 Pandemic. SKIN The Journal of Cutaneous Medicine. 2020;4(5):438-439.

17. Brzezińska-Wcisło L, Bergler-Czop B, Wcisło-Dziadecka D, et al. Co nowego w patogenezie trądziku pospolitego. Dermatol Klin. 2006;8:275-279.

18. Feliczak-Guzik A, Jagodzińska K, Nowak I. Rola hydroksykwasów w kosmetyce. Pol J Cosmetol. 2013;16:85-92.

19. Kim RH, Armstrong AW. Current state of acne treatment: highlighting lasers, photodynamic therapy and chemical peels. Dermatology online journal. 2011;17(3):2.

20. Jankowiak W, Imielski W, Pachurka J. Kosmetologia wobec problemów cery tłustej i trądzikowej. Kosmetologia Estetyczna. 2016;5(5):501-504.

21. Padlewska K. Medycyna estetyczna $i$ kosmetologia. Warszawa: Wyd. PZWL; 2014.

22. Placek W, ed. Dermatologia estetyczna. Poznań: Termedia Wydawnictwa Medyczne; 2016: 233-245.

23. Czarnecka-Operacz M, Jakubowicz O. Rola zabiegów pielęgnacyjnych w leczeniu trądziku. Przegl Dermatol. 2010;97:335-341.

24. Matusiak Ł, Szepietowski J. Izotretynoina w trądziku - schematy dawkowania $\mathrm{w}$ aspektach skuteczności, interakcji, tolerancji, bezpieczeństwa oraz kosztów terapii. Dermatol Klin. 2011;13(3):145-154.

25. Bojarowicz H, Płowiec A. Wpływ witaminy A na kondycję skóry. Probl Hig Epidemiol. 2010;91(3):352-356.

otrzymano/ received: 13.06.2021 | poprawiono/corrected: 29.06.2021 | zaakceptowano/accepted: 10.07.2021 